УДК 349.2

DOI https://doi.org/10.32844/2618-1258.2019.5-2.13

КРИВЕНКО Д.Є.

\title{
ЗМІСТ МЕДІАЦІЇ ЯК СПОСОБУ ВИРІШЕННЯ ТРУДОВИХ СПОРІВ
}

У статті проаналізовано зміст медіації як способу вирішення трудових спорів. Розкрито специфіку і значення цієї правової категорії. Охарактеризовано правову природу складників елементів медіації як способу вирішення трудових спорів. Наведено наукові матеріали у досліджуваній сфері. Наголошено, що процедура медіації має доволі універсальний характер. Вона не тільки сприяє врегулюванню правових спорів, а може також стати основою соціальних відносин розвитку суспільства, сприятиме гармонізації суспільних відносин. Визначено, що досвід медіативного вирішення трудового спору значно збільшуватиме рівень довіри у населення щодо захищеності прав, а також дозволятиме застосовувати побачені прийоми уже в більш локальних конфліктних ситуаціях, що сприятиме загальному зменшенню виникнення трудових спорів. Тому, хоча медіація і сприймається, як позадержавний інститут, проте заохочення іiї використання матиме позитивний результат для держави через зменшення навантаження на усі державні органи. 3'ясовано, що під оперативністю усунення перешкод у трудових відносинах як елементу сутності медіації варто розуміти найбільш ефективне співвідношення швидкості розгляду трудового спору із якістю та економічністю його вирішення, що дозволяє продовжувати безпосередні трудові відносини. Зроблено висновок, що застосування медіації на підприємстві як постійної практики буде змінювати рівень правової обізнаності та захисту своїх прав кожним працівником із уникненням саме стресових ситуацій. Унаслідок таких дій та все більшого порозуміння між працівниками та роботодавцем буде реалізовуватись метод заохочення правомірної діяльності та тиск $з$ боку самого колективу на осіб, що порушують трудову дисципліну, щодо припинення відповідної поведінки, адже буде розумітись цінність збереження наявного балансу та рівності в інтересах. Таким чином, медіація як спосіб розвитку психолого-комунікативних навиків суб'єктів трудових відносин полягає у зміні загального підходу до втілення трудових відносин щодо профілактики вчинення правопорушень та превентивного попередження виникнення трудових спорів.

Ключові слова: медіачія, трудові спори, спосіб вирішення конфлікту, трудовий конфлікт, прачівник, захист.

In the article the content of mediation as a way to resolve labor disputes is analyzed. The specifics and significance of this legal category are revealed. The legal nature of the constituent elements of mediation as a way of resolving labor disputes is described. Scientific materials in the researched sphere are given. It is emphasized that the mediation procedure is quite universal. It not only contributes to the settlement of legal disputes, but can become the basis of social relations for the development of society, will contribute to the harmonization of social relations. It is determined that the experience of mediating the resolution of labor disputes will significantly increase the level of public confidence in the protection of their rights, as well as allow the application of techniques already seen in more local conflict situations, which will reduce the overall occurrence of labor disputes. Therefore, although mediation is perceived as a non-state institution, encouraging its use will also have a positive effect on the state by reducing the burden on all state bodies. It was found that the efficiency of removing obstacles in labor relations, as an element of the essence of mediation, should be understood as the most effective ratio of speed of labor dispute with the quality and cost-effectiveness of its resolution, which allows to continue direct labor relations. It is concluded that the use of mediation in the

(C) КРИВЕНКО Д.Є. - аспірант кафедри трудового права та права соціального забезпечення юридичного факультету (Київський національний університет імені Тараса Шевченка) 
enterprise, as a constant practice, will change the level of legal awareness and protection of their rights by each employee to avoid stressful situations. As a result of such actions and growing understanding between employees and the employer, a method of encouraging lawful activity and pressure from the team itself on those who violate labor discipline to stop their behavior will be implemented, because the value of maintaining the existing balance and equality of interests will be understood. Thus, mediation, as a way to develop the psychological and communicative skills of the subjects of labor relations is to change the general approach to the implementation of labor relations for their prevention of offenses and preventive prevention of labor disputes.

Key words: mediation, labor disputes, way of conflict resolution, labor conflict, employee, protection.

Вступ. Право на захист своїх прав є одним із основних для кожної людини та поширюється й на трудові права. Разом з тим, аналізуючи національну практику розгляду трудових спорів у суді, можливо визначити ряд їх недоліків, як-то: надмірна тривалість, можливість невирішення самого конфлікту по суті, складна процедура виконання судового рішення. Саме тому виникає потреба у дослідженні можливості використання інших альтернативних способів вирішення трудових спорів, найбільш добровільним із яких є медіація.

Аналіз останніх досліджень та публікацій. Сьогодні питання змісту медіації як способу вирішення трудових спорів набуло значної актуальності, однак досі є малодослідженим. Так, його науковою розробкою займались такі науковці, як В.Я. Бурак, Г.С. Гончарова, Г.М. Грабовська, Н.В. Дараганова, Л.В. Зайцева, В.О. Кабанець, М.В. Колеснікова, Н.М. Крестовська, Л.В. Кулачок-Тітова, М.І. Логвиненко, Н.А. Мазаракі, О.Г. Середа, Т.А. Подковенко, М.Я. Поліщук, Ю.О. Ровинський, Ю.В. Розман, Л. Дж. Романадзе, О.І. Черкас, Н.І. Чудик-Білоусова, О.С. Щукін.

Постановка завдання. Метою статті є дослідження змісту медіації як способу вирішення трудових спорів.

Результати дослідження. На думку О.Г. Середи, «сьогодні процедура примирення сторін трудового договору виражається в активній ролі суду на стадії підготовки справи до судового розгляду і зводиться, по суті, до спроби уникнути дорогої і не завжди ефективної процедури розгляду справи в судовому засіданні шляхом укладення сторонами мирової угоди» [1, с. 41]. У цьому разі йдеться про доцільність та користь саме присудової медіації, однак і в загальному контексті вірним є твердження, що відбувається економія матеріальних та часових ресурсів обох сторін трудового спору, адже через велике навантаження на суд у поєднанні із збільшенням судових витрат сама суть звернення за захистом до суду може втрачати свою користь. Проте така ситуація не може бути підставою для нереалізації самого права на захист. Крім того, вирішення справи у суді можливе лише через окремі чітко визначені способи, що не завжди повністю підходять для конкретної ситуації, а також можуть зайняти велику кількість часу щодо виконання, що пов'язано із недоліками виконавчого провадження. Однак варто наголосити, що медіація $є$ дієвою лише у разі зацікавленості саме двох сторін трудового спору, адже в іншому разі після їі проведення все одно доведеться звертатись до суду за захистом власних прав.

На дещо інше призначення медіації звертає увагу Г.М. Грабовська, зазначаючи, що «процедура медіації має доволі універсальний характер. Вона не тільки сприяє врегулюванню правових спорів, а може стати основою соціальних відносин розвитку суспільства, сприятиме гармонізації суспільних відносин. При цьому відносини повинні вибудовуватися на основі співпраці та взаєморозуміння, а не боротьби та протистояння» [2, с. 120]. Дійсно, якщо розглядати збільшення застосування саме медіації у трудових спорах, що особливо стосується індивідуальних, то вона сприятиме знаходженню спільної мови між працівником та роботодавцем та стимулюватиме дотримання трудової дисципліни, охорони праці. Крім того, значно зменшиться рівень стресу та психологічного навантаження на кожну із сторін трудових відносин через зниження самої їх антагоністичності. Досвід медіативного вирішення трудового спору значно збільшуватиме рівень довіри у населення щодо захищеності їхніх прав, а також дозволятиме застосовувати побачені прийоми вже у більш локальних конфліктних ситуаціях, що сприятиме загальному зменшенню виникнення трудових спорів. Таким чином, хоча медіація і сприймається як позадержавний інститут, проте заохочення її використання матиме позитивний результат і для держави через зменшення навантаження на усі державні органи. 
Варто звернути увагу на Європейський кодекс поведінки для медіаторів, у якому встановлено, що для медіації «головними $є$ не правові претензії, що пов'язані з минулим, а майбутні інтереси партнерів по конфлікту і можливість збереження нормальних відносин у перспективі» [3]. Тобто ключовим завданням медіації $є$ не встановлення сторони-правопорушника у трудовому спорі або ж визначення розміру компенсації, а знаходження способу вирішення спору, за якого самі трудові правовідносини або їх завершення відповідали б інтересам обох сторін. У цьому разі використання трудового законодавства має базовий характер щодо встановлення дозволених меж діяльності та умов спільного прийнятого рішення. Разом з тим іншою стороною медіації є саме 3'ясування сутності трудового спору, його причин та однаковості їх розуміння кожною із сторін.

Зі свого боку Н.В. Дараганова, досліджуючи тему медіації в індивідуальних трудових споpax, вказує на такі причини для іiї застосування: «головна функція посередника (медіатора) під час вирішення індивідуального трудового спору за допомогою медіації полягає у сприянні та забезпеченні переговорного процесу між сторонами; медіатор допомагає сторонам обрати конкретні шляхи та способи вирішення спору; важливим аспектом медіації є її добровільність, коли сторони індивідуального трудового спору беруть участь у медіації добровільно як під час прийняття рішення про медіацію, так і в процесі ії проведення та досягнення домовленостей і виконання рішень» [4, с. 79]. Із цього твердження можливо визначити ключовий недолік медіації щодо виконання спільних рішень, адже сьогодні немає чіткого виконавчого процесу для медіативних рішень, що особливо стосується виплат різних компенсацій щодо нещасних випадків на виробництві або ж щодо поновлення на роботі. Саме тому найпершим завданням медіатора $є$ встановлення мотивів кожної із сторін для визначення сенсу проведення медіації. Варто зупинитись на діяльності самого медіатора, сутність якої полягає у забезпеченні можливості сторонам трудових відносин почути одна одну та спілкуватись для встановлення спільного рішення. Слід розрізняти психологічну сторону трудового спору щодо небажання, страху або ж недостатньої кваліфікації у сторін для самостійного вирішення та правову сторону, що розкривається у юридичних наслідках кожного із можливих варіантів вирішення спору. Отже, медіатор направляє вирішення трудового спору таким чином, щоб юридичні наслідки рішення влаштовували всі сторони.

Щодо неформальності медіації, то в межах трудових спорів ії рівень буде відрізнятись залежно від того, про які спори йдеться, - колективні, де існують постанови щодо їх врегулювання шляхом посередництва, та, власне, індивідуальні, для яких питання проведення медіації взагалі залишено поза увагою законодавця. Саме неформальність дозволяє сторонам вільно виражати свої думки без їх коректування згідно з правовими позиціями. Крім того, здатність самостійно прийняти рішення значно зменшує внутрішнє небажання його виконувати, як у разі із арбітражем або ж судовим рішенням, що мають примусовий характер. Отже, на основі проведеного дослідження щодо змісту медіації як способу вирішення трудових спорів можливо зрозуміти, що $є$ декілька його аспектів, що лише у сукупності дозволяють вірно тлумачити сутність цього правового інституту. Так, медіацію як спосіб вирішення трудових спорів слід розуміти:

1) як спосіб рівного захисту трудових прав роботодавця та працівника та інших суб’єктів трудових відносин;

2) як спосіб оперативного усунення перешкод у трудових відносинах;

3) як спосіб розвитку психолого-комунікативних навиків суб'єктів трудових відносин.

Щодо першого елементу сутності, такого як рівність захисту трудових прав усіх суб'єктів трудових відносин, то зазвичай під нею розуміють однаковий обсяг прав та обов'язків, які корелюють між собою, а також відсутність дискримінації за будь-якою із ознак. Звісно, дотримання цих положень $є$ обов'язковим у межах медіації, адже така рівність $є$ основоположною для реалізації будь-якого трудового права. Разом з тим, аналізуючи трудове законодавство, можливо виявити присутність у ньому так званої «позитивної дискримінації», щодо якої I.I. Забокрицький зазначає, що, «розглядаючи поняття “позитивна дискримінація”, варто пам'ятати, що основним складником цього терміну є все ж таки дискримінація, а вона суперечить принципу рівності. Незважаючи на поширені аргументи, що позитивна дискримінація є необхідною для того, щоб виправити попередню значну нерівність (а такі практики були запроваджені значною мірою у зв'язку з попередньою нерівністю на основі ознаки статі, раси тощо), будучи лише тимчасовою, на наше переконання, навряд чи можна вважати ії легітимною метою, необхідною у демократичному суспільстві» [5, с. 527]. В межах захисту це проявляється у тому, що пріоритетним є саме забезпечення реалізації трудових прав працівника та трудового колективу, інтереси ж роботодавця мають похідний від них характер та зазвичай захищаються лише у разі прямого їх порушення. Однак саме застосування медіації допомагає досягнути рівності у захисті, адже не має на меті 
задовольнити інтереси або зняти перешкоди для реалізації прав винятково однієї сторони. Крім того, рівність у медіації стосується й процесуальної сторони, адже ні роботодавець, ні працівник не зобов'язані доводити наявність чи відсутність вини, визначення якої у медіації не $\epsilon$ принциповим, а спільно знаходять рішення, що задовольняло б однаково повною мірою сторони трудового спору. Таким чином, рівність як сутність медіації включає у себе правову та процесуальну рівність, а також рівність перед медіатором та, власне, у його діяльності.

Наступним елементом сутності медіації є їі розуміння як способу саме оперативного усунення перешкод у трудових відносинах. Насамперед оперативність передбачає вирішення трудового спору у максимально короткі можливі строки. В судовому процесі використовується термін «розумні строки», які, однак, не уточнюються, а отже, це дає певні можливості для зловживання. В.О. Лагута визначає такі критерії розумності строку: «складність справи; поведінка заявника (суд покладає на заявника тільки обов'язок демонструвати готовність брати участь на всіх етапах розгляду); значущість питання для заявника, яке перебуває на розгляді суду» [6, с. 328]. У межах медіації на строки розгляду, відповідно, буде впливати значущість справи і рівень участі обох сторін. Крім того, значну роль відіграє професіоналізм медіатора, який має зменшити складність справи через зменшення рівня конфліктності сторін трудового спору та об’єднання їх щодо вирішення такого спору.

Наступним елементом оперативності має бути сама якість вирішення трудового спору, адже немає сенсу розглядати його швидко, якщо бажаного результату не буде досягнуто. У такому разі буде відсутня різниця між наслідками проведення медіації та суду, адже хоча перешкоди для реалізації права можуть бути усунені, воля сторін до продовження трудових відносин буде відсутня. Відповідно, для досягнення якісного вирішення трудового спору та, власне, продовження трудових відносин необхідним $є$ застосування методів примирення та донесення до сторін позитивних та негативних аспектів юридичних наслідків кожного із рішень, що вони можуть прийняти, та координації діалогу між ними. Таким чином, під оперативністю усунення перешкод у трудових відносинах як елементу сутності медіації варто розуміти найбільш ефективне співвідношення швидкості розгляду трудового спору із якістю та економічністю його вирішення, що й дозволяє продовжувати безпосередні трудові відносини.

Останнім елементом сутності медіації $є$ ії розуміння як способу розвитку психолого-комунікативних навиків суб'єктів трудових відносин. Тут варто уточнити, що йдеться про становлення єдності та уніфікованого бачення правомірної поведінки у всіх членів трудового колективу, незалежно від того, виникає індивідуальний чи колективний трудовий спір. Так, досліджуючи саме психологічний вплив медіації, А.І. Гусєв визначає, що «можливість взаємодіяти на рівні міжособистісного спілкування у неофіційних умовах дозволяє: по-перше, уникнути міфологізації та символізації фігури правопорушника для потерпілого; по-друге, уникнути механізації, обезлічування ідеї законного покарання, яка робить 3 нього психологічного потерпілого, надаючи йому усі переваги опосередковано покараного, для правопорушника. До того ж, як свідчить практика, домовленості про відшкодування матеріальних збитків, досягнуті під час проведення процедури примирення, $є$ більшими за розміром та більш реальними за формою втілення, ніж примарні судові постанови» [7, с. 10]. У контексті трудових спорів це дозволяє сторонам краще зрозуміти позицію один одного та оцінити іiі справедливість. Крім того, завдяки переговорам відбувається персональне знайомство, а отже, встановлюється контакт та взаємодія між особами, що вже значно зменшує рівень напруги та стереотипного бачення працівника й роботодавця, їх інтересів. Слід погодитись із автором, що комунікація між сторонами трудового спору сприяє більш швидкому та належному виконанню рішення, оскільки воно влаштовує обидві сторони.

Висновки. Отже, застосування медіації на підприємстві як постійної практики буде змінювати рівень правової обізнаності та захисту своїх прав кожним працівником із уникненням саме стресових ситуацій. Унаслідок таких дій та все більшого порозуміння між працівниками та роботодавцем буде реалізовуватись метод заохочення правомірної діяльності та тиск з боку самого колективу на осіб, що порушують трудову дисципліну, щодо припинення відповідної поведінки, адже буде розумітись цінність збереження наявного балансу та рівності в інтересах. Таким чином, медіація як спосіб розвитку психолого-комунікативних навиків суб'єктів трудових відносин полягає у зміні загального підходу до втілення трудових відносин щодо профілактики вчинення правопорушень та превентивного попередження виникнення трудових спорів. 


\section{Список використаних джерел:}

1. Середа О.Г. Медіація (посередництво) як альтернативний спосіб вирішення трудового спору. Право та інновації. 2017. № 2. С. 38-45.

2. Грабовська Г.М., Подковенко Т.О. Сучасні способи врегулювання індивідуальних трудових спорів. Юридичний вісник. 2018. № 3(48). С. 117-123.

3. Європейський кодекс поведінки медіаторів: міжнародний акт Європейської комісії від 02.06.2004. URL: https:cutt.ly/7ttM78S.

4. Дараганова Н.В. Медіація як один із альтернативних способів вирішення індивідуальних трудових спорів. Юридична наука. 2011. № 6. С. 77-83.

5. Забокрицький I. Рівність, гідність та пропорційність як принципи прав людини. Вісник Національного університету «Львівська політехніка». 2017. № 865. С. 521-530.

6. Лагута В.О. Критерії визначення розумних строків. Форум права. 2013. № 3. С. 328-332.

7. Гусєв А.І. Окремі психологічні аспекти впровадження медіаційних технологій у роботу 3 «латентними правопорушеннями» у шкільному середовищі. URL: https:cutt.ly/xts70wc.

ЛЮБИМОв О.к.

\section{РЕФОРМУВАННЯ ПУБЛІЧНОЇ СЛУЖБИ КРІЗЬ ПРИЗМУ ЗАБЕЗПЕЧЕННЯ СОЦАЛЬНОЇ БЕЗПЕКИ ПРОФЕСІЙНИХ ПУБЛІЧНИХ СЛУЖБОВЦІВ}

Стаття присвячена критичному аналізу результатів реформування системи публічної служби у зв'язку із забезпеченням соціальної безпеки професійних публічних службовців. Автором окреслено важливість трудоправового контексту наукового осмислення модернізації публічної служби з огляду на те, що професійна публічна служба $\epsilon$ виявом особливої трудової діяльності багатьох громадян України, недостатній рівень соціальної безпеки цих службовців створює умови, за яких працівники не спроможні гідно виконувати свої службово-трудові обов'язки, а орган публічної адміністрації унеможливлений досягати мети свого створення та функціонування. 3 огляду на це з'ясовано вплив множинних перетворень в адміністративному законодавстві про професійну публічну службу на стан забезпечення соціальної безпеки цих службовців. У цьому контексті зазначено, що в Україні $з$ 2019 р. здійснюються множинні перетворення в адміністративному законодавстві, котрі спрямовані на європеїзацію професійної публічної служби й на вирішення значного обсягу інших проблемних питань функціонування публічної служби в Україні, що тією чи іншою мірою стосуються стану забезпечення належного рівня соціальної безпеки професійних публічних службовців; погіршують стандарти забезпечення гідної праці держслужбовців, отже, їх рівень соціальної безпеки. Автором виокремлено та систематизовано основні напрями реформування професійної публічної служби як складової частини забезпечення соціальної безпеки публічних службовців. До цих напрямів реформування віднесено напрями, що обумовлені внутрішніми передумовами реформування системи публічної служби і є такими, які позначаються на стані забезпечення соціальної безпеки професійних публічних службовців (група напрямів реформування професійної публічної служби, що опосередковано позначаються на стані забезпечення соціальної безпеки професійних публічних службовців; група напрямів реформування професійної публічної служби, що безпосередньо позначаються на стані забезпечення соціальної безпеки професійних публічних службовців); напрями, що обумовлені зовнішніми переду-

(C) ЛЮБИМОВ О.К. - кандидат юридичних наук, помічник судді (Вищий господарський суд 